\title{
Serum biomarkers of polyomavirus infection and risk of lung cancer in never smokers
}

Jyoti Malhotra ${ }^{1,2}$, Tim Waterboer $^{3}$, Michael Pawlita $^{3}$, Angelika Michel $^{3}$, Qiuyin Cail ${ }^{4}$ Wei Zheng ${ }^{4}$, Yu-Tang Gao ${ }^{5}$, Qing Lan ${ }^{6}$, Nathaniel Rothman ${ }^{6}$, Hilde Langseth ${ }^{7}$, Tom K Grimsrud ${ }^{7}$, Jian-Min Yuan ${ }^{8}$, Woon-Puay Koh ${ }^{9}$, Renwei Wang ${ }^{8}$, Alan A Arslan ${ }^{10}$, Anne Zeleniuch-Jacquotte ${ }^{10}$ and Paolo Boffetta ${ }^{*, 1}$

${ }^{1}$ Icahn School of Medicine at Mount Sinai, 17 East 102 St, Floor 4 West, Room 110, New York, NY, USA; ${ }^{2}$ Rutgers Cancer Institute of New Jersey, New Brunswick, NJ, USA; ${ }^{3}$ German Cancer Research Center (DKFZ), Heidelberg, Germany; ${ }^{4}$ Vanderbilt University School of Medicine, Nashville, TN, USA; ${ }^{5}$ Shanghai Cancer Institute, Shanghai, China; ${ }^{6}$ National Cancer Institute, Rockville, MD, USA; ${ }^{7}$ Cancer Registry of Norway, Institute of Population-based Cancer Research, Oslo, Norway; ${ }^{8}$ University of Pittsburgh Graduate School of Public Health, Pittsburgh, PA, USA; ${ }^{9}$ Duke-NUS Graduate Medical School Singapore, and Saw Swee Hock School of Public Health, National University of Singapore, Singapore 117549, Singapore and ${ }^{10}$ New York University School of Medicine, New York, NY, USA

Background: Lung cancer in never smokers is a significant contributor of cancer mortality worldwide. In this analysis, we explored the role of nine human polyomaviruses, including JC virus (JCV), BK virus (BKV) and Merkel cell virus (MCV), in lung cancer development in never smokers as there are data to support that polyomaviruses are potentially carcinogenic in the human lung.

Methods: We used multiplex serology to detect serum antibodies to polyomaviruses in a nested case-control design combining lung cancer cases and controls from four cohort studies - NYU Women's Health Study (NYU-WHS), Janus Serum Bank, Shanghai Women's Health Study and Singapore Chinese Health Study (SCHS).

Results: The final analyses included 511 cases and 508 controls. Seroprevalence for each polyomavirus showed significant heterogeneity by study, but overall there were no statistically significant differences between cases and controls. In total, $69.1 \%$ of the cases and $68.7 \%$ of the controls were seropositive for JCV VP1 antibody. Seropositivity for BKV was higher at $89.0 \%$ in cases and $89.8 \%$ in controls and lower for MCV at $59.3 \%$ in cases and $61.6 \%$ in controls. Similar results were obtained after adding an additional retrospective case-control study (Xuanwei study) to the analysis.

Conclusions: Our results do not support the hypothesis that seropositivity for polyomaviruses is associated with increased lung cancer risk in never smokers. Future research to evaluate relationship between polyomavirus infection and lung carcinogenesis should focus more on evaluating the presence of virus or viral nucleic acids (DNA or RNA) in lung tumour samples.

Lung cancer in never smokers is estimated to be the seventh leading cause of cancer mortality worldwide (Sun et al, 2007), with an incidence of $10-15$ cases per 100000 person-years in the United States and Europe (Wakelee et al, 2007; Thun et al, 2008). Recognised causes of lung cancer in never smokers include second-hand smoke (IARC Working Group on the Evaluation of Carcinogenic Risks to Humans, 2004; Boffetta et al, 2009), indoor radon (National Research Council (US), 1999; Samet et al, 2009), indoor coal burning
(IARC Working Group on the Evaluation of Carcinogenic Risks to Humans, 2010), occupational carcinogens (Zeka et al, 2006) and outdoor air pollution (Loomis et al, 2013). In addition, association of lung cancer risk with genetic variants on chromosome $5 \mathrm{p} 15.33$ (Hsiung et al, 2010; Truong et al, 2010), 6q (Amos et al, 2010) and 13q31.3 (Li et al, 2009) has been identified in never smokers. However, these known causes explain only a small proportion of never-smoking lung cancer cases (Sisti and Boffetta, 2012). There is

*Correspondence: Professor P Boffetta; E-mail: paolo.boffetta@mssm.edu

Received 10 May 2016; revised 22 July 2016; accepted 9 August 2016; published online 15 September 2016

(c) 2016 Cancer Research UK. All rights reserved 0007 - 0920/16 
a need to investigate other risk factors associated with lung cancer in never smokers and one potential area of further research is in carcinogenesis associated with infectious agents. This is especially relevant as there is evidence to support that chronic inflammation from factors such as infection may be involved in lung carcinogenesis (Engels, 2008; Shiels et al, 2015). An infectious aetiology can be relevant to lung cancer in both ever- and never smokers, but it might be easier to identify in the latter group because of the lack of potential confounding by tobacco smoking.

Polyomaviruses are non-enveloped DNA viruses that may be potentially carcinogenic in the human lung. The first two identified human polyomaviruses - JCV and BKV - were first isolated in 1971 (Gardner et al, 1971; Padgett et al, 1971). From 2007 onwards, eight more human polyomaviruses have been identified (Allander et al, 2007; Gaynor et al, 2007; Feng et al, 2008; Schowalter et al, 2010; van der Meijden et al, 2010; Buck et al, 2012). Serological studies till now suggest that polyomaviruses subclinically infect the general population with rates ranging from 35 to $90 \%$ Among the polyomaviruses known to date, JC virus (JCV) and Merkel cell virus (MCV) have attracted the strongest attention for a possible role in human cancer because of their presence in various tumours, their oncogenic potential in several animal models and the interaction with the Rb family of tumour suppressor genes (Bouvard et al, 2012). It has been suggested that the presence of JCV correlates with lung cancer and various other human neoplasms, including colorectal, gastric, prostate, oesophageal cancers, brain tumours and B-cell lymphoma (Weber and Major, 1997; Galateau-Salle et al, 1998; Reiss and Khalili, 2003; Del Valle et al, 2004, 2005; Hori et al, 2005; Theodoropoulos et al, 2005; Murai et al, 2007). In animal studies also, there are reported pulmonary tumours derived from JCV T-antigen (TAg) in a transgenic mouse model (Noguchi et al, 2013). Further investigation of polyomavirus infection in lung cancer is needed to explore a potential association.

The gold standard to investigate the role of transforming viral agents in human carcinogenesis is by detection of persistent, biologically active virus infection in the target organ. However, this is difficult to explore in lung cancer especially as tumour samples are available only from a selected group of cases undergoing surgery, and are difficult to obtain from unbiased series of noncancer controls. In these circumstances, use of validated serological markers represents a promising alternative, especially in studies aimed at establishing the presence of an association rather than obtaining a precise estimate of its magnitude. Polyomaviruses studied so far lead to strong and over time stable antibody responses to structural viral proteins, that is, the major capsid protein VP1 (Kjaerheim et al, 2007; Antonsson et al, 2010a) and are highly sensitive cumulative markers of past infection. Recently, multiplex serology assays have been developed that allows simultaneous measurement of antibody responses to multiple proteins (Waterboer et al, 2005). In this analysis, we explored the role of polyomaviruses in lung cancer development in never smokers using a multiplex assay to detect serum antibodies to capsid proteins of these polyomaviruses. We have used a nested case-control design to pool data from four prospective cohort studies and also one retrospective study.

\section{PATIENTS AND METHODS}

Study design and population. Our current study is a nested casecontrol study of cases identified from four established prospective cohorts. Never-smoking cases of lung cancer were selected among members of two prospective cohort studies of Europeans - NYU Women's Health Study (WHS) (Toniolo et al, 1995) and Janus Serum Bank (Toniolo et al, 1995) and two prospective studies of
Asians - Shanghai Women's Health Study (SWHS) (Zheng et al, 2005) and Singapore Chinese Health Study (SCHS) (Koh et al, 2010). The four cohorts have been established in the 1970s-1990s, and several rounds of follow-up have been successfully conducted, enabling the identification of incident cancer cases. Controls were matched to cases on the basis of the following established criteria: gender, never-smoking status, age at entry, calendar period of entry and other relevant criteria that are specific to each cohort (e.g. recruitment area). Consent has been obtained from all participants for future use of serum samples collected at the time of enrolment into the cohort in each of the four participating studies. We also included a retrospective case-control study in Asian Women from Xuanwei, China (Lan et al, 2002; Shen et al, 2009) in the secondary analysis. In this study, serum samples from cases were obtained after diagnosis. Study approval was also obtained from the Institutional Review Board at Icahn School of Medicine at Mount Sinai and from ethical review boards for each participating cohort.

Laboratory analysis. A $100 \mu \mathrm{l}$ prediagnostic serum sample was obtained from each case and control from all four participating cohort studies and shipped to the Division of Molecular Diagnostics of Oncogenic Infections at the German Cancer Research Center (Deutsches Krebsforschungszentrum, DKFZ) in Heidelberg for the analysis of serological markers of infection with polyomaviruses. Serological analyses were performed by fluorescent bead-based multiplex serology as previously described (Waterboer et al, 2005; Kjaerheim et al, 2007; Michel et al, 2009; Antonsson et al, 2010a), allowing simultaneous quantification of antibodies up to 100 antigens in a high-throughput assay. Briefly, full-length viral proteins were expressed in bacteria in fusion with an N-terminal glutathione $S$-transferase (GST) domain. Glutathione crosslinked to casein was covalently bound to fluorescence labelled polystyrene beads (SeroMap; Luminex Corp., Austin, TX, USA), and GST-fusion proteins were affinity-purified directly on the beads. Plasma dilutions were incubated with the same volume of mixed bead sets, at a final dilution of 1:000. Bound antibodies were detected with biotinylated goat-anti human $\operatorname{IgG}(\mathrm{H}+\mathrm{L})$ secondary antibody and streptavidin-R-phycoerythrin. Beads were examined in a Luminex 200 analyzer (xMAP, Luminex Corp.) that identifies the different bead types by their internal colour and quantifies the antibody bound to the viral antigen on the different bead types via the median R-phycoerythrin fluorescence intensity (MFI) of at least 100 beads of each bead type (Waterboer et al, 2005; Kjaerheim et al, 2007). The serological analyses included viral capsid protein-1 (VP1) and T-antigens (TAg) of nine human polyomaviruses: JC virus (JCVP1, JCTAg), $\mathrm{BK}$ virus (BKVP1, BKTAg), KI virus (KI VP1), WU virus (WU VP1), trichodysplasia spinulosa-associated polyoma virus (TSV VP1, TSV TAg), Merkel cell polyoma virus (MCV344 VP1, MCV small T Ag, MCV large $\mathrm{T}$ Ag), human polyoma virus 6 (HPyV6 VP1, HPyV6 Tag), human polyoma virus 7 (HPyV7 VP1, HPyV7 Tag) and human polyoma virus 10 (HPyV10 VP1, HPyV10 TAg). With respect to serological markers of polyomavirus infection, the Pearson's correlation coefficients for the net MFI values for 188 sera analysed on two consecutive days for antibodies to BKV and JCV VP1 range from 0.83 to 1.00 (median, 0.96) (Antonsson et al, 2010a).

Statistical analysis. To calculate the association between markers of JCV and other polyomavirus infection and lung cancer risk, odds ratios and $95 \%$ confidence intervals were calculated using logistic regression in which lung cancer status was the dependent variable (outcome) and positivity to each serological markers was the main independent variables (determinant). Seropositivity for each polyomavirus was defined as virus-specific VP1 antibody $\geqslant 250 \mathrm{MFI}$ and $\geqslant 400 \mathrm{MFI}$ for TAg (except for seropositivity for MCV small TAg where MFI $\geqslant 200$ considered to be seropositive). 
Cut points were determined, and were chosen for each PyV by visual inspection of frequency distribution curves (percentile plots) for the inflection points of all sera tested as done in prior studies (Karagas et al, 2006; Michael et al, 2008; Paulson et al, 2010; Antonsson et al, 2010e). Analyses were also repeated after stratifying by gender, race/ethnicity, histology and quantiles of the serological marker MFI. All analyses were performed using STATA 11 (College Station, TX, USA).

\section{RESULTS}

The study included 511 cases and 508 controls from four cohort studies; baseline characteristics for each study are listed in Table 1. Shanghai Women's Health Study included only Asian women, Janus Serum Bank included both European men (39.4\%) and women (60.8\%), NYU-WHS had only women mostly of European descent (79.7\%), while SCHS only had Asian participants. There were variations in mean age of sample collection (range: 45.1-65.8 years) and mean age at diagnosis (range: $64.6-70.9$ years) between the four studies. Another major difference in the four studies was in the time interval between sample collection and cancer diagnosis. Majority of the participants in Janus and NYU-WHS had samples collected more than 10 years before the time of cancer diagnosis. Conversely, in SCHS and SWHS studies, most of the participants had samples collected within 10 years of cancer diagnosis. Age at sample collection, gender and race/ethnicity were similar between cases and controls $(P$-value $>0.05)$. Addition of Xuanwei study to the analysis increased the study size to 720 cases and 717 controls. As Xuanwei was a retrospective cohort study in Asian women, the samples were collected around the time of cancer diagnosis.

The results with seropositivity for each polyomavirus are listed in Table 2. The percentage of participants seropositive for each polyomavirus was similar between cases and controls after pooling results from all four studies. Seventy per cent of the cases and $67.9 \%$ of the controls were seropositive for JCV VP1 antibody. On combining results for seropositivity to either JCV VP1 or JCV TAg, $72.0 \%$ of the cases and $71.5 \%$ of the controls were seropositive. Similarly, we found no significant differences in cases and controls for each of the polyomaviruses for VP1 antibody seropositivity as well as combined seropositivity for VP1 and TAg (positive for at least one). These seroprevalences for polyomaviruses were also similar for cases and controls after including Xuanwei study (retrospective case-control study) in the analysis. The largest histological group was adenocarcinoma (58\% of all cancers) and analysis restricted only to adenocarcinoma cases and their matched controls in presented in Table 2. There were no significant differences in seropositivity for polyomaviruses on stratified analysis although the subgroups for other histologies other than adenocarcinoma were small in size.

Seropositivity for each polyomavirus VP1 stratified by study is listed in Table 3. In the stratified analysis by study, seroprevalence for each polyomavirus showed significant heterogeneity by study but overall there were no statistical significant differences between cases and controls in any of the five studies. For instance, MCV showed seroprevalence against VP1 in cases ranging from 36.0 to $76.7 \%$. Overall, seropositivity for each polyomavirus was higher in the Asian Cohorts compared with cohorts with Caucasian patients. For example, seropositivity for JCV VP1 in Janus study (predominantly Caucasian) was $59.5 \%$ in cases compared with $77.2 \%$ in SWHS and $75.4 \%$ in SCHS (Asian cohorts).

In addition, we did not find any differences in seropositivity between cases and controls in our stratified analysis based on time interval from sample collection to cancer diagnosis (Table 4) or gender. We also divided the participants based on their MFI into quartiles for each polyomavirus and then compared the mean MFI between the quartiles for cases and controls to explore for any potential association between antibody levels and seropositivity. However, cases and controls did not differ significantly in any of these analyses.

\section{DISCUSSION}

Our study is the largest epidemiological study in never smokers to investigate if infection with polyomaviruses as measured by

Table 1. Baseline characteristics of participating studies

\begin{tabular}{|c|c|c|c|c|c|c|c|}
\hline & $\begin{array}{l}\text { Cases }^{a} \\
(n=511)\end{array}$ & $\begin{array}{l}\text { Controls }^{a} \\
(n=508)\end{array}$ & Janus & NYU-WHS & SCHS & SWHS & Xuanwei study ${ }^{b}$ \\
\hline n, Cases/controls & - & - & $126 / 124$ & $64 / 64$ & $114 / 114$ & $207 / 206$ & $209 / 209$ \\
\hline $\begin{array}{l}\text { Age at sample collection } \\
\text { Mean } \pm \text { s.d. }\end{array}$ & $56.0 \pm 11.0$ & $56.1 \pm 11.1$ & $45.1 \pm 8.7$ & $55.0 \pm 8.1$ & $65.8 \pm 7.8$ & $57.7 \pm 8.50$ & $50.7 \pm 9.6$ \\
\hline $\begin{array}{l}\text { Gender } \\
\text { Female }\end{array}$ & 433 (84.7\%) & 430 (84.7\%) & 152 (60.8\%) & $128(100 \%)$ & 170 (74.6\%) & 413 (100\%) & 418 (100\%) \\
\hline $\begin{array}{l}\text { Race/ethnicity } \\
\text { White } \\
\text { Asian } \\
\text { Other }\end{array}$ & $\begin{array}{c}177(34.6 \%) \\
322(63.0 \%) \\
12(2.4 \%)\end{array}$ & $\begin{array}{c}175(34.5 \%) \\
321(63.2 \%) \\
12(2.3 \%)\end{array}$ & $\begin{array}{c}250(100 \%) \\
- \\
-\end{array}$ & $\begin{aligned} 102 & (79.7 \%) \\
2 & (1.6 \%) \\
24 & (18.8 \%)\end{aligned}$ & $\begin{array}{c}- \\
228(100 \%) \\
-\end{array}$ & $\begin{array}{c}- \\
413(100 \%) \\
-\end{array}$ & $\begin{array}{c}- \\
418(100 \%) \\
-\end{array}$ \\
\hline $\begin{array}{l}\text { Age at diagnosis } \\
\text { Mean } \pm \text { s.d. }\end{array}$ & $66.9 \pm 9.9$ & - & $65.3 \pm 11.0$ & $70.9 \pm 9.4$ & $70.5 \pm 8.1$ & $64.6 \pm 9.2$ & $50.6 \pm 9.4$ \\
\hline $\begin{array}{l}\text { Histology } \\
\text { Adenocarcinoma } \\
\text { Squamous cell } \\
\text { Small cell }\end{array}$ & $\begin{array}{c}592 \text { (58.1\%) } \\
54(5.2 \%) \\
214(21.0 \%)\end{array}$ & $\begin{array}{l}- \\
- \\
-\end{array}$ & $\begin{aligned} 65 & (51.6 \%) \\
7 & (5.6 \%) \\
13 & (10.3 \%)\end{aligned}$ & $\begin{array}{l}32(50 \%) \\
5(7.8 \%) \\
11(17.2 \%)\end{array}$ & $\begin{array}{c}74(64.9 \%) \\
5(4.4 \%) \\
20(17.5 \%)\end{array}$ & $\begin{array}{c}127(61.4 \%) \\
10(4.8 \%) \\
63(30.4 \%)\end{array}$ & $\begin{array}{c}185(88.5 \%) \\
24(11.5 \%) \\
-\end{array}$ \\
\hline $\begin{array}{l}\text { Interval between sample collection and } \\
\text { cancer diagnosis (years) } \\
\quad \leqslant 5 \\
5-10 \\
>10\end{array}$ & $\begin{array}{l}135(26.4 \%) \\
172(33.7 \%) \\
204(39.9 \%)\end{array}$ & $\begin{array}{l}- \\
- \\
-\end{array}$ & $\begin{array}{c}9(7.1 \%) \\
7(5.6 \%) \\
110(87.3 \%)\end{array}$ & $\begin{array}{c}4(6.3 \%) \\
10(15.6 \%) \\
50(78.1 \%)\end{array}$ & $\begin{array}{c}61(53.5 \%) \\
49(42.3 \%) \\
4(3.5 \%)\end{array}$ & $\begin{array}{r}61(29.5 \%) \\
106(51.2 \%) \\
40(19.3 \%)\end{array}$ & $\begin{array}{l}\mathrm{b} \\
- \\
-\end{array}$ \\
\hline \multicolumn{8}{|c|}{ 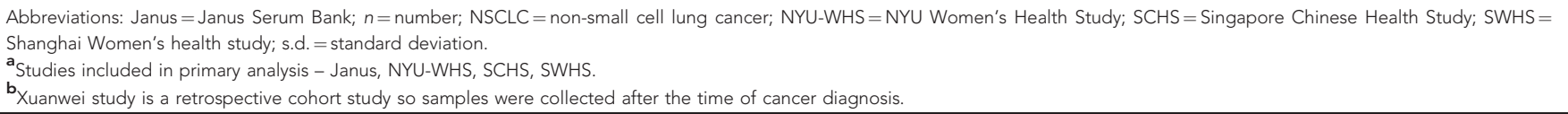 } \\
\hline
\end{tabular}


Table 2. Seropositivity of polyomaviruses and association with lung cancer

\begin{tabular}{|c|c|c|c|c|c|c|}
\hline & \multicolumn{2}{|c|}{ Cases } & \multicolumn{2}{|c|}{ Controls } & \multirow[b]{2}{*}{ Odds ratio $(95 \% \mathrm{Cl})$} & \multirow[b]{2}{*}{$P$-value } \\
\hline & $n$ & $\%$ & $n$ & $\%$ & & \\
\hline JCV (VP1) & 353 & 69.1 & 349 & 68.7 & $1.02(0.78-1.33)$ & 0.90 \\
\hline JCV (VP1 \pm TAg) & 368 & 72.0 & 363 & 71.5 & $1.03(0.78-1.35)$ & 0.84 \\
\hline BKV (VP1) & 455 & 89.0 & 456 & 89.8 & $0.93(0.62-1.38)$ & 0.71 \\
\hline BKV (VP1 \pm TAg) & 455 & 89.0 & 456 & 89.8 & $0.93(0.62-1.38)$ & 0.71 \\
\hline KI (VP1) & 434 & 84.9 & 445 & 87.6 & $0.80(0.56-1.14)$ & 0.22 \\
\hline WU (VP1) & 490 & 95.9 & 492 & 96.9 & $0.76(0.39-1.47)$ & 0.41 \\
\hline TSV (VP1) & 391 & 76.5 & 387 & 76.2 & $1.02(0.76-1.36)$ & 0.90 \\
\hline TSV (VP1 \pm TAg) & 392 & 76.7 & 388 & 76.4 & $1.02(0.76-1.36)$ & 0.13 \\
\hline MCV (VP1) & 303 & 59.3 & 313 & 61.6 & $0.91(0.71-1.17)$ & 0.45 \\
\hline $\begin{array}{l}\text { MCV (VP1 } \pm \text { small } \\
\text { TAg } \pm \text { large TAg) }\end{array}$ & 305 & 59.7 & 314 & 61.8 & $0.91(0.71-1.18)$ & 0.49 \\
\hline HPyV6 (VP1) & 393 & 76.9 & 399 & 78.5 & $0.91(0.68-1.22)$ & 0.53 \\
\hline HPyV6 (VP1 \pm TAg) & 393 & 76.9 & 400 & 78.7 & $0.90(0.67-1.21)$ & 0.48 \\
\hline HPyV7 (VP1) & 330 & 64.6 & 332 & 65.4 & $0.97(0.75-1.25)$ & 0.80 \\
\hline HPyV7 (VP1 \pm TAg) & 333 & 65.2 & 334 & 65.8 & $0.97(0.75-1.26)$ & 0.85 \\
\hline HPyV10 (VP1) & 492 & 96.3 & 496 & 97.6 & $0.63(0.30-1.30)$ & 0.21 \\
\hline HPyV10 (VP1 \pm TAg) & 492 & 96.3 & 497 & 97.8 & $0.57(0.27-1.22)$ & 0.15 \\
\hline \multicolumn{7}{|c|}{ Analysis including adenocarcinoma only } \\
\hline JCV (VP1) & 207 & 69.5 & 196 & 66.7 & $1.14(0.80-1.61)$ & 0.47 \\
\hline $\mathrm{JCP}(\mathrm{VP} 1 \pm \mathrm{TAg})$ & 216 & 72.5 & 204 & 69.4 & $1.16(0.81-1.66)$ & 0.41 \\
\hline BKV (VP1) & 265 & 88.9 & 268 & 91.2 & $0.78(0.45-1.34)$ & 0.37 \\
\hline BKV (VP1 \pm TAg) & 265 & 88.9 & 268 & 91.2 & $0.78(0.45-1.34)$ & 0.37 \\
\hline KI (VP1) & 251 & 84.3 & 258 & 87.8 & $0.75(0.47-1.19)$ & 0.22 \\
\hline WU (VP1) & 285 & 95.6 & 287 & 97.6 & $0.53(0.21-1.36)$ & 0.19 \\
\hline TSV (VP1) & 230 & 77.2 & 219 & 74.5 & $1.16(0.79-1.69)$ & 0.44 \\
\hline TSV (VP1 \pm TAg) & 230 & 77.2 & 220 & 74.8 & $1.14(0.78-1.66)$ & 0.5 \\
\hline MCV (VP1) & 162 & 54.4 & 184 & 62.6 & $0.71(0.51-0.99)$ & 0.04 \\
\hline MCV (VP1 \pm small & 163 & 54.7 & 184 & 62.6 & $0.72(0.52-1.00)$ & 0.05 \\
\hline TAg \pm large TAg) & & & & & & \\
\hline HPyV6 (VP1) & 226 & 75.8 & 239 & 81.3 & $0.72(0.49-1.07)$ & 0.11 \\
\hline HPyV6 (VP1 \pm TAg) & 226 & 75.8 & 240 & 81.6 & $0.71(0.47-1.05)$ & 0.09 \\
\hline HPyV7 (VP1) & 188 & 63.1 & 204 & 69.4 & $0.75(0.54-1.06)$ & 0.11 \\
\hline HPyV7 (VP1 $\pm \mathrm{TAg})$ & 190 & 63.8 & 205 & 69.7 & $0.76(0.54-1.08)$ & 0.12 \\
\hline HPyV10 (VP1) & 282 & 94.6 & 285 & 96.9 & $0.56(0.24-1.28)$ & 0.17 \\
\hline HPyV10 (VP1 \pm TAg) & 282 & 94.6 & 286 & 97.3 & $0.49(0.21-1.17)$ & 0.11 \\
\hline
\end{tabular}

seroprevalence and quantity of antibodies against viral structural proteins are associated with lung cancer risk. After pooling serological results from four cohort studies using a nested case-control design, we did not find any significant differences in serological measurements of antibodies against each of the polyomaviruses between the cases and controls. Similar results were obtained from an additional retrospective case-control study. Our results do not support the hypothesis that seropositivity for polyomaviruses is associated with increased lung cancer risk in never smokers.

Serological studies have indicated asymptomatic JCV infection in up to $80-90 \%$ of the adult population (Weber and Major, 1997; DeCaprio and Garcea, 2013), which is similar to that reported in our analysis and, which may be activated in immunodeficient patients, resulting in progressive multifocal leukoencephalopathy (Frisque et al, 1984; White and Khalili, 2004, 2005). JC virus can transform cells, as shown by effects such as growth in agar, rapid division, prolongation of life span, unstable multicentric chromosomes, centric and acentric rings, and the ability to form dense foci in culture (Frisque et al, 1984). Intravenous or intracranial inoculation of JCV into experimental animals has been found to cause astrocytomas, glioblastomas, neuroblastomas and medulloblastomas (Reiss and Khalili, 2003). In addition, transgenic mice expressing the JCV T-antigen developed pituitary adenomas or malignant peripheral nerve sheath tumours (Gordon et al, 2000; Reiss and Khalili, 2003). The molecular mechanisms underlying oncogenesis by JCV could centre on its encoded regulatory products, T-antigens and agnoprotein. The JCV T-antigen can inactivate $\mathrm{p} 53$ and members of the $\mathrm{pRb}$ family, and deregulate the Wnt signalling pathway through stabilisation of $\beta$-catenin to promote uncontrolled proliferation and immortal survival (Ricciardiello et al, 2001; Khalili et al, 2003; Niv et al, 2005; White and Khalili, 2005). A number of studies investigating JCV in lung cancer tissue samples have been performed. In a Japanese analysis of JCV TAg in 103 lung carcinomas and 18 normal lung tissues, $68 \%$ of lung carcinomas were positive, compared with only $11 \%$ of normal lung tissue $(P<0.05)$, indicating that JCV may be involved in lung carcinogenesis (Zheng et al, 2007). In another study by the same group, 25 of 62 lung cancers had TAg compared with only 4 of 23 normal lung tissues $(P=0.048)$ (Abdel-Aziz et al, 2007). In contrast, an Italian study reported that only one tumour sample out of 78 was positive (Giuliani et al, 2007). KI and WU polyomaviruses have also been identified in respiratory tract 
Table 3. Seropositivity of polyomaviruses and association with lung cancer stratified by participating study

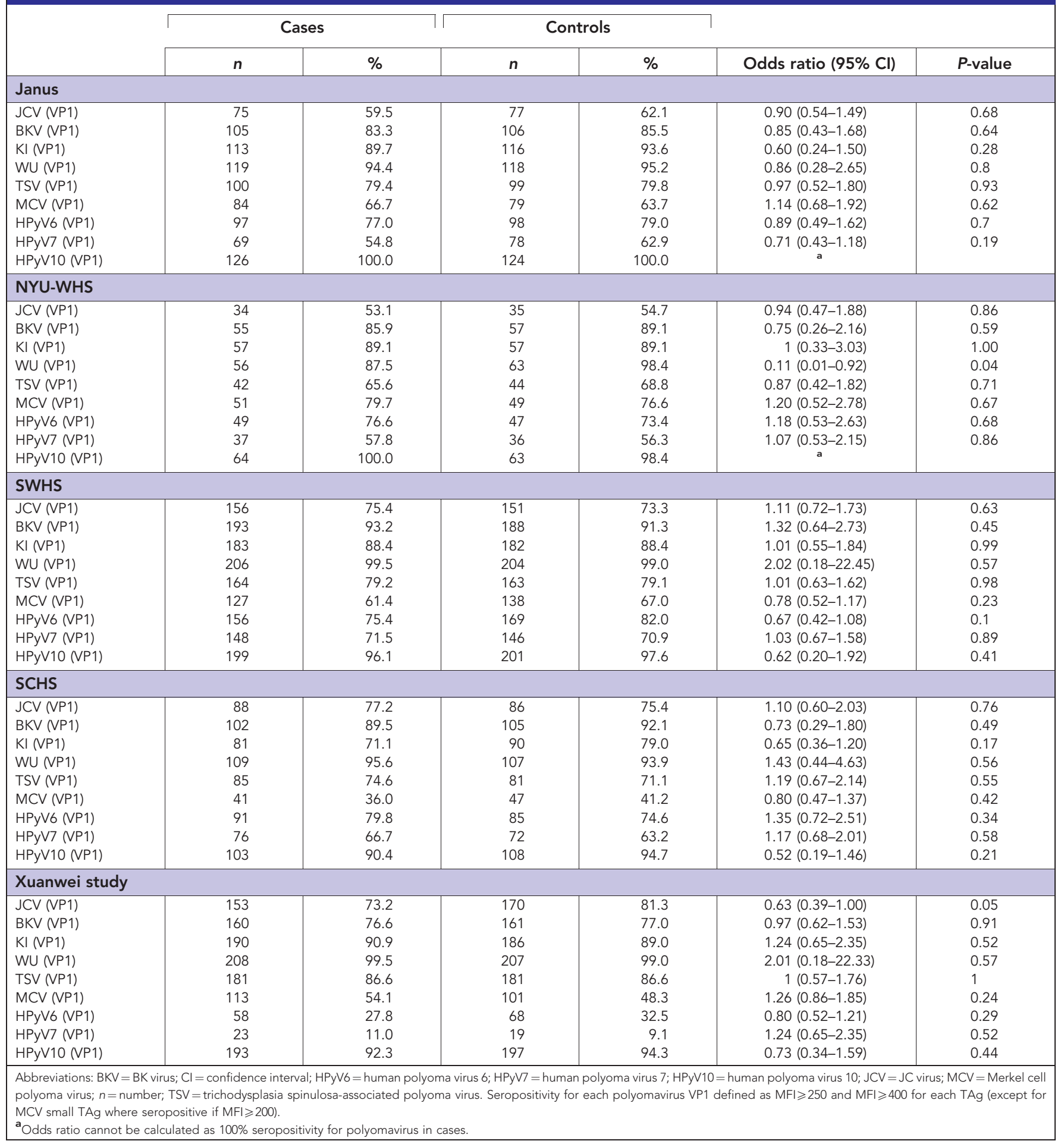

specimens, especially in children with respiratory tract infections (Ren et al, 2008; Okada et al, 2013). This raises the question whether KI or WU subclinical infection in the respiratory tract may lead to chronic inflammatory changes and ultimately lung carcinogenesis. Merkel cell virus is associated with Merkel cell carcinomas in immunocompromised hosts (Feng et al, 2008). There have been studies conducted to investigate the prevalence of MCV in lung tumours and these have shown variable results with some studies showing MCPyV DNA present in more than $15 \%$ of the tumours (Joh et al, 2010). One of these studies also demonstrated the expression of large $\mathrm{T}$ RNA transcripts and antigen in lung cancer, thus indicating possible viral integration (Hashida et al, 2013). A Greek study also reported MCV DNA in $9.1 \%$ of lung tumours. Moreover, increased BRAF expression and decreased Bcl-2 expression were noted in MCV DNA-positive samples (Lasithiotaki et al, 2013). These results suggest that viral DNA integration may potentially activate cancer pathways and is an area for future investigation.

Recent developments have resulted in increased specificity and sensitivity of serological markers of past infection with known and suspected oncogenic viruses. Multiplex serology allows quantitative analysis of antibodies to multiple recombinant structural and 
Table 4. Seropositivity of polyomaviruses and association with lung cancer stratified by interval between sample collection and cancer diagnosis

\begin{tabular}{|c|c|c|c|c|}
\hline & $\begin{array}{l}\text { Cases } \\
n(\%)\end{array}$ & $\begin{array}{c}\text { Controls } \\
n(\%)\end{array}$ & $\begin{array}{l}\text { Odds ratio } \\
(95 \% \mathrm{Cl})\end{array}$ & $P$-value \\
\hline \multicolumn{5}{|l|}{$\leqslant 5$ years } \\
\hline JCV (VP1) & $101(74.8)$ & $98(73.1)$ & $1.09(0.63-1.88)$ & 0.75 \\
\hline BKV (VP1) & 125 (92.6) & $119(88.8)$ & $1.58(0.68-3.64)$ & 0.29 \\
\hline KI (VP1) & 109 (80.7) & 109 (81.3) & $0.96(0.52-1.77)$ & 0.9 \\
\hline WU (VP1) & $131(97.0)$ & $128(95.5)$ & $1.54(0.42-5.57)$ & 0.51 \\
\hline TSV (VP1) & $100(74.1)$ & $101(75.4)$ & $0.93(0.54-1.62)$ & 0.81 \\
\hline MCV (VP1) & $75(55.6)$ & $74(55.2)$ & $1.01(0.63-1.64)$ & 0.96 \\
\hline HPyV6 (VP1) & $105(77.8)$ & $102(76.1)$ & $1.10(0.62-1.94)$ & 0.75 \\
\hline HPyV7 (VP1) & 92 (68.2) & 83 (61.9) & $1.31(0.80-2.17)$ & 0.29 \\
\hline HPyV10 (VP1) & $129(95.6)$ & $126(94.0)$ & $1.37(0.46-4.05)$ & 0.58 \\
\hline \multicolumn{5}{|l|}{$5-10$ years } \\
\hline JCV (VP1) & $131(76.2)$ & $125(72.7)$ & $1.20(0.74-1.95)$ & 0.46 \\
\hline BKV (VP1) & $155(90.1)$ & 159 (92.4) & $0.75(0.35-1.58)$ & 0.45 \\
\hline KI (VP1) & $142(82.6)$ & $155(90.1)$ & $0.52(0.27-0.98)$ & 0.04 \\
\hline WU (VP1) & 169 (98.3) & $167(97.1)$ & $1.69(0.40-7.17)$ & 0.48 \\
\hline TSV (VP1) & $138(80.2)$ & $127(73.8)$ & $1.44(0.87-2.39)$ & 0.16 \\
\hline MCV (VP1) & 89 (51.7) & $102(59.3)$ & $0.74(0.48-1.13)$ & 0.16 \\
\hline HPyV6 (VP1) & $133(77.3)$ & $145(84.3)$ & $0.64(0.37-1.09)$ & 0.1 \\
\hline HPyV7 (VP1) & 115 (66.9) & $119(69.2)$ & $0.90(0.57-1.41)$ & 0.64 \\
\hline HPyV10 (VP1) & $162(94.2)$ & 169 (98.3) & $0.29(0.08-1.06)$ & 0.06 \\
\hline \multicolumn{5}{|l|}{$>10$ years } \\
\hline JCV (VP1) & $121(59.3)$ & $126(62.4)$ & 0.88 (0.59-1.31) & 0.53 \\
\hline BKV (VP1) & $175(85.8)$ & $178(88.1)$ & $0.81(0.46-1.45)$ & 0.49 \\
\hline KI (VP1) & $183(89.7)$ & $181(89.6)$ & $1.01(0.53-1.92)$ & 0.97 \\
\hline WU (VP1) & 190 (93.1) & $197(97.5)$ & $0.34(0.12-0.97)$ & 0.05 \\
\hline TSV (VP1) & $153(75.0)$ & $159(78.7)$ & $0.81(0.51-1.29)$ & 0.38 \\
\hline MCV (VP1) & 139 (68.1) & 137 (67.8) & $1.01(0.67-1.54)$ & 0.95 \\
\hline HPyV6 (VP1) & $155(76.0)$ & $152(75.3)$ & $1.04(0.66-1.64)$ & 0.86 \\
\hline HPyV7 (VP1) & $123(60.3)$ & $130(64.4$ & $0.84(0.56-1.26)$ & 0.4 \\
\hline HPyV10 (VP1) & $201(98.5$ & $201(99.5$ & $0.33(0.03-3.23)$ & 0.34 \\
\hline
\end{tabular}

regulatory proteins in parallel in a high-throughput fashion (Dillner, 2005; Waterboer et al, 2005). This increases the sensitivity and in comparison with conventional screening ELISA increases the specificity of antibody detection as it has been shown for HPV (Dillner, 2005; Waterboer et al, 2005), polyomaviruses (Kjaerheim et al, 2007) and Helicobacter pylori (Michel et al, 2009). The protein antigens used in the assay for our analysis have been shown to allow very sensitive and virus-type-specific antibody detection (Waterboer et al, 2005; Kjaerheim et al, 2007; Paulson et al, 2010; Liang et al, 2012; Teras et al, 2015). Moreover, there is ample evidence supporting the use of serological markers in detection of polyomaviruses. Systemic infections, as observed with all polyomaviruses studied so far, lead to strong and over time stable antibody responses to structural viral proteins, that is, the major capsid protein VP1 (Kjaerheim et al, 2007; Antonsson et al, 2010a) and are thus highly sensitive cumulative markers of past infection, while antibodies to polyomaviral T-Antigens are rare and usually of low titer. However, strong antibody responses to the large TAg of MCV have been found to be very significantly associated with Merkel cell carcinoma (Paulson et al, 2010). Development of strong antibody responses to oncogenic proteins E6 and E7 has also been observed in patients with HPV-associated cervical (Meschede et al, 1998) or oropharyngeal (Zumbach et al, 2000; Liang et al, 2012) cancers, thus suggesting that antibodies to early, transformation-associated proteins could be diagnostic markers for malignancies driven by these viral oncogenes.

One strength of our study is the large sample size after pooling data and samples from five large lung cancer studies in comparison with previous studies exploring association between lung cancer and infectious agents (Littman et al, 2005; Chaturvedi et al, 2010;
Koshiol et al, 2011; Anantharaman et al, 2014). Moreover, in four of the five studies, we had access to samples collected before tumour development, thus avoiding potential bias from reverse causality and inadequate selection of controls. Our study also had a representation from different geographical areas. Moreover, in addition to JCV and BKV, we report the seroprevalence results for seven other human polyomaviruses that have been identified recently (after 2007) and, therefore, data for these polyomaviruses in literature are limited. One limitation of our study is that the MFI cutoff value used to determine seropositivity in this study is somewhat arbitrary, although carefully examined (Gossai et al, 2016). We did perform sensitivity analyses and found the seroprevalence data to be very robust to alterations in the cutoff. Also, we observed variation on seroprevalence of polyomaviruses based on ethnicity and geographical area which may make the interpretation of results difficult. In addition, we did not adjust for other potential confounders such as second-hand smoking and radon exposure as data for these confounders were not available across all five studies. We also did not adjust for multiple comparisons, but this may not be clinically relevant as we did not find significant association between polyomaviruses seroprevelence and lung cancer risk. We have not included measurement of polyomavirus Simian virus 40 (SV 40) seroprevalence in our study. Simian virus 40 seroprevalence has been reported to be anywhere between 9 and $12.7 \%$ in the general population and higher at $26 \%$ in patients with malignant mesothelioma in some studies (Poulin and DeCaprio, 2006; Mazzoni et al, 2012; Comar et al, 2014). However, other studies with conflicting results have shown that this low level seroprevalnce to SV40 is actually an artefact due to cross-reactivity with other related human polyomaviruses such 
as BKV and JCV (Poulin and DeCaprio, 2006; Kjaerheim et al, 2007; Shah, 2007).

In conclusion, we did not find an increased lung cancer risk is association with seropositivity for polyomaviruses including JCV. Therefore, future research should focus on exploring viral replication in tumour in combination with serological markers of infection especially as polyomavirus exposure can vary considerably across different populations and geographical areas as demonstrated by our study.

\section{ACKNOWLEDGEMENTS}

This work was supported by National Cancer Institute (5UH2CA169111-02) and in part by R37CA070867 and UM1CA182910.

\section{CONFLICT OF INTEREST}

The authors declare no conflict of interest.

\section{REFERENCES}

Abdel-Aziz HO, Murai Y, Hong M, Kutsuna T, Takahashi H, Nomoto K, Murata S, Tsuneyama K, Takano Y (2007) Detection of the JC virus genome in lung cancers: possible role of the T-antigen in lung oncogenesis. Appl Immunohistochem Mol Morphol 15: 394-400.

Allander T, Andreasson K, Gupta S, Bjerkner A, Bogdanovic G, Persson MA, Dalianis T, Ramqvist T, Andersson B (2007) Identification of a third human polyomavirus. J Virol 81: 4130-4136.

Amos CI, Pinney SM, Li Y, Kupert E, Lee J, De Andrade MA, Yang P, Schwartz AG, Fain PR, Gazdar A, Minna J, Wiest JS, Zeng D, Rothschild H, Mandal D, You M, Coons T, Gaba C, Bailey-Wilson JE, Anderson MW (2010) A susceptibility locus on chromosome 6q greatly increases lung cancer risk among light and never smokers. Cancer Res 70: 2359-2367.

Anantharaman D, Gheit T, Waterboer T, Halec G, Carreira C, AbediArdekani B, Mckay-Chopin S, Zaridze D, Mukeria A, SzeszeniaDabrowska N, Lissowska J, Mates D, Janout V, Foretova L, Bencko V, Rudnai P, Fabianova E, Tjonneland A, Travis RC, Boeing H, Quiros JR, Johansson M, Krogh V, Bueno-De-Mesquita HB, Kotanidou A, Clavel-Chapelon F, Weiderpass E, Johansson M, Pawlita M, Scelo G, Tommasino M, Brennan P (2014) No causal association identified for human papillomavirus infections in lung cancer. Cancer Res 74: 3525-3534.

Antonsson A, Green AC, Mallitt KA, O’rourke PK, Pandeya N, Pawlita M, Waterboer T, Neale RE (2010a) Prevalence and stability of antibodies to 37 human papillomavirus types - a population-based longitudinal study. Virology 407: 26-32.

Antonsson A, Green AC, Mallitt KA, O'rourke PK, Pawlita M, Waterboer T, Neale RE (2010e) Prevalence and stability of antibodies to the BK and JC polyomaviruses: a long-term longitudinal study of Australians. J Gen Virol 91: $1849-1853$.

Boffetta P, Tubiana M, Hill C, Boniol M, Aurengo A, Masse R, Valleron AJ, Monier R, De The G, Boyle P, Autier P (2009) The causes of cancer in France. Ann Oncol 20: 550-555.

Bouvard V, Baan RA, Grosse Y, Lauby-Secretan B, El Ghissassi F, Benbrahim-Tallaa L, Guha N, Straif K. WHO International Agency for Research on Cancer Monograph Working Group (2012) Carcinogenicity of malaria and of some polyomaviruses. Lancet Oncol 13: 339-340.

Buck CB, Phan GQ, Raiji MT, Murphy PM, Mcdermott DH, Mcbride AA (2012) Complete genome sequence of a tenth human polyomavirus. J Virol 86: 10887.

Chaturvedi AK, Gaydos CA, Agreda P, Holden JP, Chatterjee N, Goedert JJ, Caporaso NE, Engels EA (2010) Chlamydia pneumoniae infection and risk for lung cancer. Cancer Epidemiol Biomarkers Prev 19: 1498-1505.
Comar M, Wong C, Tognon M, Butel JS (2014) Neutralizing and IgG antibodies against simian virus 40 in healthy pregnant women in Italy. PLoS One 9: e110700.

DeCaprio JA, Garcea RL (2013) A cornucopia of human polyomaviruses. Nat Rev Microbiol 11: 264-276.

Del Valle L, Enam S, Lara C, Miklossy J, Khalili K, Gordon J (2004) Primary central nervous system lymphoma expressing the human neurotropic polyomavirus, JC virus, genome. J Virol 78: 3462-3469.

Del Valle L, White MK, Enam S, Pina Oviedo S, Bromer MQ, Thomas RM, Parkman HP, Khalili K (2005) Detection of JC virus DNA sequences and expression of viral $\mathrm{T}$ antigen and agnoprotein in esophageal carcinoma. Cancer 103: 516-527.

Dillner J (2005) Toward 'serolomics': papillomavirus serology is taking a technologic lead in high-throughput multiplexed antibody analysis. Clin Chem 51: 1768-1769.

Engels EA (2008) Inflammation in the development of lung cancer: epidemiological evidence. Expert Rev Anticancer Ther 8: 605-615.

Feng H, Shuda M, Chang Y, Moore PS (2008) Clonal integration of a polyomavirus in human Merkel cell carcinoma. Science 319: 1096-1100.

Frisque RJ, Bream GL, Cannella MT (1984) Human polyomavirus JC virus genome. J Virol 51: 458-469.

Galateau-Salle F, Bidet P, Iwatsubo Y, Gennetay E, Renier A, Letourneux M, Pairon JC, Moritz S, Brochard P, Jaurand MC, Freymuth F (1998) Detection of SV40-like DNA sequences in pleural mesothelioma, bronchopulmonary carcinoma and other pulmonary diseases. Dev Biol Stand 94: 147-152.

Gardner SD, Field AM, Coleman DV, Hulme B (1971) New human papovavirus (B.K.) isolated from urine after renal transplantation. Lancet 1: $1253-1257$.

Gaynor AM, Nissen MD, Whiley DM, Mackay IM, Lambert SB, Wu G, Brennan DC, Storch GA, Sloots TP, Wang D (2007) Identification of a novel polyomavirus from patients with acute respiratory tract infections. PLoS Pathog 3: e64.

Giuliani L, Favalli C, Syrjanen K, Ciotti M (2007) Human papillomavirus infections in lung cancer. Detection of E6 and E7 transcripts and review of the literature. Anticancer Res 27: 2697-2704.

Gordon J, Del Valle L, Otte J, Khalili K (2000) Pituitary neoplasia induced by expression of human neurotropic polyomavirus, JCV, early genome in transgenic mice. Oncogene 19: 4840-4846.

Gossai A, Waterboer T, Nelson HH, Michel A, Willhauck-Fleckenstein M, Farzan SF, Hoen AG, Christensen BC, Kelsey KT, Marsit CJ, Pawlita M, Karagas MR (2016) Seroepidemiology of human polyomaviruses in a US population. Am J Epidemiol 183: 61-69.

Hashida Y, Imajoh M, Nemoto Y, Kamioka M, Taniguchi A, Taguchi T, Kume M, Orihashi K, Daibata M (2013) Detection of Merkel cell polyomavirus with a tumour-specific signature in non-small cell lung cancer. Br J Cancer 108: 629-637.

Hori R, Murai Y, Tsuneyama K, Abdel-Aziz HO, Nomoto K, Takahashi H, Cheng CM, Kuchina T, Harman BV, Takano Y (2005) Detection of JC virus DNA sequences in colorectal cancers in Japan. Virchows Arch 447: 723-730.

Hsiung CA, Lan Q, Hong YC, Chen CJ, Hosgood HD, Chang IS, Chatterjee N, Brennan P, Wu C, Zheng W, Chang GC, Wu T, Park JY, Hsiao CF, Kim YH, Shen H, Seow A, Yeager M, Tsai YH, Kim YT, Chow WH, Guo H, Wang WC, Sung SW, Hu Z, Chen KY, Kim JH, Chen Y, Huang L, Lee KM, Lo YL, Gao YT, Kim JH, Liu L, Huang MS, Jung TH, Jin G, Caporaso N, Yu D, Kim CH, Su WC, Shu XO, Xu P, Kim IS, Chen YM, Ma H, Shen M, Cha SI, Tan W, Chang CH, Sung JS, Zhang M, Yang TY, Park KH, Yuenger J, Wang CL, Ryu JS, Xiang Y, Deng Q, Hutchinson A, Kim JS, Cai Q, Landi MT, Yu CJ, Park JY, Tucker M, Hung JY, Lin CC, Perng RP, Boffetta P, Chen CY, Chen KC, Yang SY, Hu CY, Chang CK, Fraumeni Jr JF, Chanock S, Yang PC, Rothman N, Lin D (2010) The 5p15.33 locus is associated with risk of lung adenocarcinoma in never-smoking females in Asia. PLoS Genet; e-pub ahead of print 5 August 2010; doi:10.1371/journal.pgen.1001051.

IARC Working Group on the Evaluation of Carcinogenic Risks to Humans (2004) Tobacco smoke and involuntary smoking. IARC Monogr Eval Carcinog Risks Hum 83: 1-1438.

IARC Working Group on the Evaluation of Carcinogenic Risks to Humans (2010) Household use of solid fuels and high-temperature frying. IARC Monogr Eval Carcinog Risks Hum 95: 1-430. 
Joh J, Jenson AB, Moore GD, Rezazedeh A, Slone SP, Ghim SJ, Kloecker GH (2010) Human papillomavirus (HPV) and Merkel cell polyomavirus (MCPyV) in non small cell lung cancer. Exp Mol Pathol 89: 222-226.

Karagas MR, Nelson HH, Sehr P, Waterboer T, Stukel TA, Andrew A, Green AC, Bavinck JN, Perry A, Spencer S, Rees JR, Mott LA, Pawlita M (2006) Human papillomavirus infection and incidence of squamous cell and basal cell carcinomas of the skin. J Natl Cancer Inst 98: 389-395.

Khalili K, Del Valle L, Otte J, Weaver M, Gordon J (2003) Human neurotropic polyomavirus, JCV, and its role in carcinogenesis. Oncogene 22: 5181-5191.

Kjaerheim K, Roe OD, Waterboer T, Sehr P, Rizk R, Dai HY, Sandeck H, Larsson E, Andersen A, Boffetta P, Pawlita M (2007) Absence of SV40 antibodies or DNA fragments in prediagnostic mesothelioma serum samples. Int J Cancer 120: 2459-2465.

Koh WP, Yuan JM, Wang R, Lee HP, Yu MC (2010) Body mass index and smoking-related lung cancer risk in the Singapore Chinese Health Study. Br J Cancer 102: 610-614.

Koshiol J, Rotunno M, Gillison ML, van Doorn LJ, Chaturvedi AK, Tarantini L, Song H, Quint WG, Struijk L, Goldstein AM, Hildesheim A, Taylor PR, Wacholder S, Bertazzi PA, Landi MT, Caporaso NE (2011) Assessment of human papillomavirus in lung tumor tissue. J Natl Cancer Inst 103: 501-507.

Lan Q, Chapman RS, Schreinemachers DM, Tian L, He X (2002) Household stove improvement and risk of lung cancer in Xuanwei, China. J Natl Cancer Inst 94: 826-835.

Lasithiotaki I, Antoniou KM, Derdas SP, Sarchianaki E, Symvoulakis EK, Psaraki A, Spandidos DA, Stathopoulos EN, Siafakas NM, Sourvinos G (2013) The presence of Merkel cell polyomavirus is associated with deregulated expression of BRAF and Bcl-2 genes in non-small cell lung cancer. Int J Cancer 133: 604-611.

Li YJ, Tsai YC, Chen YC, Christiani DC (2009) Human papilloma virus and female lung adenocarcinoma. Semin Oncol 36: 542-552.

Liang C, Marsit CJ, Mcclean MD, Nelson HH, Christensen BC, Haddad RI, Clark JR, Wein RO, Grillone GA, Houseman EA, Halec G, Waterboer T, Pawlita M, Krane JF, Kelsey KT (2012) Biomarkers of HPV in head and neck squamous cell carcinoma. Cancer Res 72: 5004-5013.

Littman AJ, Jackson LA, Vaughan TL (2005) Chlamydia pneumoniae and lung cancer: epidemiologic evidence. Cancer Epidemiol Biomarkers Prev 14: $773-778$.

Loomis D, Grosse Y, Lauby-Secretan B, El Ghissassi F, Bouvard V, Benbrahim-Tallaa L, Guha N, Baan R, Mattock H, Straif K. International Agency for Research on Cancer Monograph Working Group, I. (2013) The carcinogenicity of outdoor air pollution. Lancet Oncol 14: $1262-1263$

Mazzoni E, Corallini A, Cristaudo A, Taronna A, Tassi G, Manfrini M, Comar M, Bovenzi M, Guaschino R, Vaniglia F, Magnani C, Casali F, Rezza G, Barbanti-Brodano G, Martini F, Tognon MG (2012) High prevalence of serum antibodies reacting with simian virus 40 capsid protein mimotopes in patients affected by malignant pleural mesothelioma. Proc Natl Acad Sci USA 109: 18066-18071.

Meschede W, Zumbach K, Braspenning J, Scheffner M, Benitez-Bribiesca L, Luande J, Gissmann L, Pawlita M (1998) Antibodies against early proteins of human papillomaviruses as diagnostic markers for invasive cervical cancer. J Clin Microbiol 36: 475-480.

Michael KM, Waterboer T, Sehr P, Rother A, Reidel U, Boeing H, Bravo IG, Schlehofer J, Gartner BC, Pawlita M (2008) Seroprevalence of 34 human papillomavirus types in the German general population. PLoS Pathog 4: e1000091.

Michel A, Waterboer T, Kist M, Pawlita M (2009) Helicobacter pylori multiplex serology. Helicobacter 14: 525-535.

Murai Y, Zheng HC, Abdel Aziz HO, Mei H, Kutsuna T, Nakanishi Y, Tsuneyama K, Takano Y (2007) High JC virus load in gastric cancer and adjacent non-cancerous mucosa. Cancer Sci 98: 25-31.

National Research Council (US). Committee on Health Risks of Exposure to Radon (BEIR VI) (1999) Health Effects of Exposure to Radon: BEIR VI. The National Academies Press: Washington, DC, USA.

Niv Y, Goel A, Boland CR (2005) JC virus and colorectal cancer: a possible trigger in the chromosomal instability pathways. Curr Opin Gastroenterol 21: 85-89.

Noguchi A, Kikuchi K, Ohtsu T, Yoshiwara M, Nakamura Y, Miyagi Y, Zheng H, Takano Y (2013) Pulmonary tumors associated with the JC virus T-antigen in a transgenic mouse model. Oncol Rep 30: 2603-2608.
Okada M, Hamada H, Sato-Maru H, Shirato Y, Honda T, Muto A, Hayashi K, Terai M (2013) WU polyomavirus detected in respiratory tract specimens from young children in Japan. Pediatr Int 55: 536-537.

Padgett BL, Walker DL, Zurhein GM, Eckroade RJ, Dessel BH (1971) Cultivation of papova-like virus from human brain with progressive multifocal leucoencephalopathy. Lancet 1: 1257-1260.

Paulson KG, Carter JJ, Johnson LG, Cahill KW, Iyer JG, Schrama D, Becker JC, Madeleine MM, Nghiem P, Galloway DA (2010) Antibodies to merkel cell polyomavirus $\mathrm{T}$ antigen oncoproteins reflect tumor burden in merkel cell carcinoma patients. Cancer Res 70: 8388-8397.

Poulin DL, DeCaprio JA (2006) Is there a role for SV40 in human cancer? J Clin Oncol 24: 4356-4365.

Reiss K, Khalili K (2003) Viruses and cancer: lessons from the human polyomavirus, JCV. Oncogene 22: 6517-6523.

Ren L, Gonzalez R, Xie Z, Zhang J, Liu C, Li J, Li Y, Wang Z, Kong X, Yao Y, Hu Y, Qian S, Geng R, Yang Y, Vernet G, Paranhos-Baccala G, Jin Q, Shen K, Wang J (2008) WU and KI polyomavirus present in the respiratory tract of children, but not in immunocompetent adults. J Clin Virol 43: 330-333.

Ricciardiello L, Chang DK, Laghi L, Goel A, Chang CL, Boland CR (2001) Mad-1 is the exclusive JC virus strain present in the human colon, and its transcriptional control region has a deleted 98-base-pair sequence in colon cancer tissues. J Virol 75: 1996-2001.

Samet JM, Avila-Tang E, Boffetta P, Hannan LM, Olivo-Marston S, THUN MJ, Rudin CM (2009) Lung cancer in never smokers: clinical epidemiology and environmental risk factors. Clin Cancer Res 15: 5626-5645.

Schowalter RM, Pastrana DV, Pumphrey KA, Moyer AL, Buck CB (2010) Merkel cell polyomavirus and two previously unknown polyomaviruses are chronically shed from human skin. Cell Host Microbe 7: 509-515.

Shah KV (2007) SV40 and human cancer: a review of recent data. Int J Cancer 120: $215-223$.

Shen M, Chapman RS, Vermeulen R, Tian L, Zheng T, Chen BE, Engels EA, He X, Blair A, Lan Q (2009) Coal use, stove improvement, and adult pneumonia mortality in Xuanwei, China: a retrospective cohort study. Environ Health Perspect 117: 261-266.

Shiels MS, Katki HA, Hildesheim A, Pfeiffer RM, Engels EA, Williams M, Kemp TJ, Caporaso NE, Pinto LA, Chaturvedi AK (2015) Circulating lnflammation markers, risk of lung cancer, and utility for risk stratification. J Natl Cancer Inst; e-pub ahead of print 28 July 2015; doi:10.1093/jnci/djv199.

Sisti J, Boffetta P (2012) What proportion of lung cancer in never-smokers can be attributed to known risk factors? Int J Cancer 131: 265-275.

Sun S, Schiller JH, Gazdar AF (2007) Lung cancer in never smokers - a different disease. Nat Rev Cancer 7: 778-790.

Teras LR, Rollison DE, Pawlita M, Michel A, Blase JL, Willhauck-Fleckenstein M, Gapstur SM (2015) Prediagnostic circulating polyomavirus antibody levels and risk of non-Hodgkin lymphoma. Cancer Epidemiol Biomarkers Prev 24: 477-480.

Theodoropoulos G, Panoussopoulos D, Papaconstantinou I, Gazouli M, Perdiki M, Bramis J, Lazaris A (2005) Assessment of JC polyoma virus in colon neoplasms. Dis Colon Rectum 48: 86-91.

Thun MJ, Hannan LM, Adams-Campbell LL, Boffetta P, Buring JE, Feskanich D, Flanders WD, Jee SH, Katanoda K, Kolonel LN, Lee IM, Marugame T, Palmer JR, Riboli E, Sobue T, Avila-Tang E, Wilkens LR, Samet JM (2008) Lung cancer occurrence in never-smokers: an analysis of 13 cohorts and 22 cancer registry studies. PLoS Med 5: e185.

Toniolo PG, Levitz M, Zeleniuch-Jacquotte A, Banerjee S, Koenig KL, Shore RE, Strax P, Pasternack BS (1995) A prospective study of endogenous estrogens and breast cancer in postmenopausal women. J Natl Cancer Inst 87: 190-197.

Truong T, Hung RJ, Amos CI, Wu X, Bickeboller H, Rosenberger A, Sauter W, Illig T, Wichmann HE, Risch A, Dienemann H, Kaaks R, Yang P, Jiang R, Wiencke JK, Wrensch M, Hansen H, Kelsey KT, Matsuo K, Tajima K, Schwartz AG, Wenzlaff A, Seow A, Ying C, Staratschek-Jox A, Nurnberg P, Stoelben E, Wolf J, Lazarus P, Muscat JE, Gallagher CJ, Zienolddiny S, Haugen A, van der Heijden HF, Kiemeney LA, Isla D, Mayordomo JI, Rafnar T, Stefansson K, Zhang ZF, Chang SC, Kim JH, Hong YC, Duell EJ, Andrew AS, Lejbkowicz F, Rennert G, Muller H, Brenner H, Le Marchand L, Benhamou S, Bouchardy C, Teare MD, Xue X, Mclaughlin J, Liu G, Mckay JD, Brennan P, Spitz MR (2010) Replication of lung cancer susceptibility loci at chromosomes $15 \mathrm{q} 25,5 \mathrm{p} 15$, and $6 \mathrm{p} 21$ : a pooled analysis from the International Lung Cancer Consortium. J Natl Cancer Inst 102: 959-971.

van der Meijden E, Janssens RW, Lauber C, Bouwes Bavinck JN, Gorbalenya AE, Feltkamp MC (2010) Discovery of a new human polyomavirus associated 
with trichodysplasia spinulosa in an immunocompromized patient. PLoS Pathog 6: e1001024.

Wakelee HA, Chang ET, Gomez SL, Keegan TH, Feskanich D, Clarke CA, Holmberg L, Yong LC, Kolonel LN, Gould MK, West DW (2007) Lung cancer incidence in never smokers. J Clin Oncol 25: 472-478.

Waterboer T, Sehr P, Michael KM, Franceschi S, Nieland JD, Joos TO, Templin MF, Pawlita M (2005) Multiplex human papillomavirus serology based on in situ-purified glutathione s-transferase fusion proteins. Clin Chem 51: 1845-1853.

Weber T, Major EO (1997) Progressive multifocal leukoencephalopathy: molecular biology, pathogenesis and clinical impact. Intervirology $\mathbf{4 0}$ 98-111.

White MK, Khalili K (2004) Polyomaviruses and human cancer: molecular mechanisms underlying patterns of tumorigenesis. Virology 324: 1-16.

White MK, Khalili K (2005) Expression of JC virus regulatory proteins in human cancer: potential mechanisms for tumourigenesis. Eur J Cancer 41: 2537-2548.

Zeka A, Mannetje A, Zaridze D, Szeszenia-Dabrowska N, Rudnai P, Lissowska J, Fabianova E, Mates D, Bencko V, Navratilova M, Cassidy A, Janout V, Travier N, Fevotte J, Fletcher T, Brennan P, Boffetta P (2006) Lung cancer and occupation in nonsmokers: a multicenter case-control study in Europe. Epidemiology 17: 615-623.

Zheng H, Abdel Aziz HO, Nakanishi Y, Masuda S, Saito H, Tsuneyama K, Takano Y (2007) Oncogenic role of JC virus in lung cancer. J Pathol 212: 306-315.

Zheng W, Chow WH, Yang G, Jin F, Rothman N, Blair A, Li HL, Wen W, Ji BT, Li Q, Shu XO, Gao YT (2005) The Shanghai Women's Health Study: rationale, study design, and baseline characteristics. Am J Epidemiol 162: $1123-1131$.

Zumbach K, Hoffmann M, Kahn T, Bosch F, Gottschlich S, Gorogh T, Rudert H, Pawlita M (2000) Antibodies against oncoproteins E6 and E7 of human papillomavirus types 16 and 18 in patients with head-and-neck squamous-cell carcinoma. Int J Cancer 85: 815-818.

This work is published under the standard license to publish agreement. After 12 months the work will become freely available and the license terms will switch to a Creative Commons AttributionNonCommercial-Share Alike 4.0 Unported License. 